\title{
O papel da História na legitimação do Sacro Império Romano-Germânico em Marsílio de Pádua
}

Fabiano Arndt Araújo 1

Resumo: No início do século XIV, apesar do relativo enfraquecimento do Papado, exilado em Avignon, e da perda de prestígio e influência sofrida pelo Sacro Império Romano-Germânico, o clássico conflito medieval entre Império e Papado reacendeu-se nas figuras de Luís IV da Baviera e João XXII. Nesse contexto, Marsílio Mainardini, professor da Universidade de Paris, optou por colocar-se ao lado de Luís IV em oposição ao pontífice, produzindo tratados cujo objetivo era dar legitimidade ao Império, demonstrando a autonomia do poder secular. No presente trabalho, nosso objetivo foi analisar o tratado $D e$ Translatione Imperii, identificando os argumentos lançados por Marsílio de Pádua para a legitimação do Sacro Império Romano-Germânico e analisando os diferentes aspectos inerentes a tais argumentos. De modo geral, destacamos a forma como as ideias de Marsílio inserem-se em um contexto maior, de "secularização" das reflexões políticas, que marca a transição do Medievo à Modernidade.

Palavras-chave: Império Medieval. Supremo Legislador Humano. Translatio Imperii.

Abstract: In the early fourteenth century, despite the relative weakness of the Papacy, in exile in Avignon, and the loss of prestige and influence suffered by the Holy Roman Empire, the classic medieval conflict between Empire and Papacy was rekindled in the figures of Louis IV of Bavaria and John XXII. In this context, Marsilio Mainardini, professor at the University of Paris, has chosen to put himself alongside Louis IV in opposition to the pontiff, producing treaties whose aim was to give legitimacy to the empire, demonstrating the autonomy of secular power. In this study, our goal was to analyze the treatise De Translatione Imperii, identifying the arguments

${ }^{1}$ Bacharel e licenciado em História pela Universidade Federal do Paraná. 
launched by Marsilius of Padua to the legitimacy of the Holy Roman Empire and analyzing the different aspects inherent to such arguments. In general, we highlight how Marsilio ideas fall into a larger context of "secularization" of political reflections, which marks the transition from the Middle Ages to Modernity.

Keywords: Medieval Empire. Human Supreme Lawgiver. Translatio Imperii.

\section{Introdução:}

A transição do Medievo à Modernidade foi um período de grandes transformações. Entre os séculos XI e XIII, a cristandade latina viveu um período de expansão e aquecimento, observáveis no crescimento demográfico e no aumento da produção e do consumo, contexto que possibilitou o florescimento das cidades. A emancipação urbana gerou novas realidades políticas, econômicas e sociais, além de diferentes percepções religiosas, dentro ou fora da ortodoxia, ao longo dos séculos XIII, XIV e XV. No que tange ao pensamento, um dos traços marcantes dessa série de rupturas foi o aparecimento de novas propostas políticas que conciliavam a tradição clássica e medieval-cristã às demandas específicas daquela conjuntura.

Nesse sentido, percebem-se concepções que apontam cada vez mais na direção de uma visão "laica" da comunidade política civil, em muito influenciadas pela retomada do pensamento político aristotélico. Muitos nomes seguiram neste caminho, entre eles Dante Alighieri, Guilherme de Ockham e, já no século XV, Nicolau Maquiavel. Ainda no século XIV, um dos nomes de maior destaque e inovação foi o de 
Marsílio Mainardini (1280-1343), mais conhecido como Marsílio de Pádua. O pensador paduano era de origem "burguesa", ligado a essa nova categoria social urbana que há algum tempo ganhava destaque; sua ampla formação incluía estudos de medicina, teologia e filosofia, nas universidades de Pádua, sua cidade natal, e Paris, onde também foi professor e reitor.

A obra de Marsílio de Pádua significou uma importante evolução dentro do pensamento político medieval, tanto pela retomada da filosofia aristotélica através de Tomás de Aquino quanto pela intenção de colocar o poder civil acima do religioso na esfera temporal. A partir disso, estudar o pensamento de Marsílio constitui um dos pontos-chave para o entendimento tanto das relações políticas e institucionais quanto da filosofia política na Baixa Idade Média, bem como uma forma de perceber as rupturas e continuidades entre o Medievo e a Modernidade.

Marsílio de Pádua, por suas ideias que poderíamos considerar "revolucionárias" para o século XIV, foi um dos pensadores mais notáveis e inovadores do período. Em sua principal obra, o tratado Defensor Pacis, publicado em 1326, o autor combate a teoria da Plenitudo Potestatis, segundo a qual o papa possuiria plenos poderes, tanto temporais como espirituais, o que, na concepção curialista (da cúria papal), manteria a unidade político-social, a ordem e a paz. A conjuntura da Baixa Idade Média sem dúvidas pesou sobre o 
pensamento marsiliano, que foi influenciado, entre outras coisas, pela disputa entre Filipe IV e Bonifácio VIII, pelos debates entre Espirituais e Comunidade dentro da Ordem Franciscana, pelos conflitos políticos da Península Itálica e pelo convívio que o autor teve com juristas de renome, como João de Jandum e Pedro d'Albano. ${ }^{2}$

Nossa intenção neste trabalho é analisar, à luz do contexto histórico e da teoria política medieval, os argumentos desenvolvidos por Marsílio de Pádua em seu tratado De Translatione Imperii, escrito como complemento a sua principal obra, o Defensor Pacis. Nesse tratado Marsílio continua o ataque desferido contra a Igreja e o Papado, construindo uma "genealogia" do Sacro Império Romano-Germânico, segundo a qual as origens deste remontariam ao próprio Império Romano. O principal objetivo do autor é claro: dar ao Império uma origem e um desenvolvimento histórico independentes da instituição eclesiástica, o que contribuiria para confirmar sua tese maior de que, na esfera terrena, o gládio temporal estaria acima do espiritual.

$\mathrm{O}$ texto a seguir estrutura-se em duas seções. Na primeira traçaremos um panorama sobre o contexto no qual Marsílio de Pádua viveu, e quais seriam as demandas conjunturais que pesaram sobre sua escrita. Na segunda analisaremos a fonte já mencionada, o tratado $D e$

2 SOUZA, José Antônio de Camargo Rodrigues de; BERTELLONI, Francisco; PIAIA, Gregório. Introdução. In: PÁDUA, Marsílio de. O Defensor da Paz. Petrópolis: Vozes, 1997. p. 13-63. Passim. 
Translatione Imperii, no qual Marsílio constrói uma "genealogia" do Sacro Império Romano-Germânico.

\section{Marsílio de Pádua, suas ideias e seu contexto}

Não há consenso sobre a data de seu nascimento, mas é provável que Marsílio tenha nascido entre 1275 e 1280, na cidade de Pádua, no norte da Península Itálica. Membro de uma família tradicional, pertencente à "classe administrativa da comuna"3, seu pai, Bonmatteo Mainardini, foi notário na Universidade de Pádua ${ }^{4}$, o que indica que provavelmente Marsílio cresceu em um ambiente culto e favorável aos estudos. Marsílio estudou Medicina, Direito e, mais tarde, Filosofia e Teologia. Seus estudos iniciaram-se ainda em Pádua e foram continuados na Universidade de Paris, onde Marsílio chegou a ser reitor no ano de 1313. Após atuar como representante pontifício em Pádua e depois de ter servido a senhores gibelinos lombardos entre 1319 e 1324 , Marsílio regressou a Paris, onde, com a ajuda de seu colega e amigo João de Jandum, escreveu sua principal obra, o tratado Defensor Pacis, concluído por volta de 1324. Em 23 de outubro de 1327 o Defensor Pacis seria condenado como herético pelo Papa João XXII na bula Licet Iuxta Doctrinam.

${ }^{3}$ BAYONA, Bernardo; ROCHE, Pedro (Ed.). Marsílio de Pádua: sobre el poder del Imperio y del Papa. Madri: Biblioteca Nueva, 2004. p. 14-15.

${ }^{4}$ SOUZA, José Antonio de C. R. de. Op. Cit. Passim. 
Sobre a escrita do Defensor Pacis pesam diversos elementos conjunturais ainda do período de estudos de Marsílio de Pádua, como a querela entre o monarca francês Filipe IV e o papa Bonifácio VIII, as questões entre Espirituais e Comunidade dentro da Ordem Franciscana e, sobretudo, as disputas entre Luís IV da Baviera e o papa João XXII. Neste tratado, cuja "[...] finalidade é demolir a doutrina hierocrática do Papado", Marsílio sustenta uma de suas principais teses, segundo a qual a usurpação da autoridade secular pelo Papado seria a causa da perturbação da ordem e da ausência da paz. Realocar a autoridade secular, retirando-a das mãos do pontífice, seria o modo de restabelecer a ordem e a paz.

Para Souza ${ }^{6}$, o pensamento de Marsílio de Pádua tem como objetivo maior o restabelecimento da paz, da tranquilidade, da harmonia social, da ordem e do equilíbrio que se havia rompido. Para que isso fosse possível, seria necessária a existência de uma autoridade a quem todos se submetessem; tal autoridade, para Marsílio, não seria a Igreja, mas sim o poder secular. Marsílio submete o poder espiritual ao civil, idealizando uma sociedade onde predominariam a Lei, o Direito e o bem comum, e onde o poder seria instituído pelo povo e exercido pelo Imperador, governante civil com missão também espiritual. $\mathrm{O}$ poder

\footnotetext{
${ }^{5}$ RUBINSTEIN, Nicolai. Marsílio de Pádua. In: LOYN, Henry R. (Org.). Dicionário da Idade Média. Rio de Janeiro: Zahar, 1997. p. 591.

${ }^{6}$ SOUZA, José Antonio de C. R. de. Introdução. In: PÁDUA, Marsílio de. Defensor Menor. Petrópolis: Vozes, 1991. Passim.
} 
secular seria, portanto, estabelecido por Deus e independente do espiritual, devendo ser exercido por todas as pessoas. Não por acaso, muitos pensadores destacam a originalidade e a radicalidade do pensamento político de Marsílio de Pádua, enxergando nele um importante ponto da transição do Medievo à Modernidade.

A querela entre os poderes espiritual e temporal foi uma realidade e um dos traços marcantes da história do período medieval. O que Jacques Le Goff ${ }^{7}$ chamou de "Cristandade bicéfala", ou seja, o conflito entre Papado e Império, dois poderes com pretensões à supremacia universal, constitui a face mais célebre desta querela. No início do século XIV, apesar da perda da força do Papado, exilado em Avignon, da ascensão das monarquias e de uma relativa perda de prestígio pelo Império, esse conflito reacendeu-se nas figuras do pontífice João XXII e do Imperador Luís IV da Baviera. Foi justamente nesse contexto que Marsílio de Pádua escreveu suas obras.

O tratado intitulado De Translatione Imperii, em português, Sobre a Transferência do Império, permaneceu anônimo até o século XVI, quando, após a primeira edição impressa do Defensor Pacis (1522), supôs-se que a obra também pertenceria a Marsílio de Pádua. Segundo nos informam Bayona e Roche ${ }^{8}$, apesar de anônimo, o tratado

\footnotetext{
${ }^{7}$ LE GOFF, Jacques. A civilização do Ocidente Medieval. Lisboa: Editorial Estampa, 1984.

${ }^{8}$ BAYONA, Bernardo; ROCHE, Pedro (Ed.). Marsílio de Pádua: sobre el poder del Imperio y del Papa. Madri: Biblioteca Nueva, 2004, p. 49-54. Passim.
} 
de Marsílio foi usado como "prova histórica" pelo humanista Konrad Peutinger ao menos em duas ocasiões: em 1519, para apoiar a eleição de Carlos V à sucessão de Maximiliano I, em oposição a Francisco I da França, apoiado pelo pontífice; e em 1530, na controvérsia entre Clemente VII e Afonso d'Este sobre a possessão de Modena. A primeira versão impressa do De Translatione Imperii ocorreria em 1555, na cidade de Basiléia.

A data de redação do tratado é imprecisa, mas tudo indica que ele tenha sido escrito provavelmente entre 1324 e 1326, na cidade de Paris, logo após a escrita do Defensor Pacis, com o qual possui uma conexão literal. Como vimos, a proposta marsiliana era a de desconstruir a teoria da Plenitudo Potestatis papal, o que já iniciara em sua obra inaugural.

Cabe indicar que o supracitado tratado foi uma espécie de continuação da obra maior de Marsílio de Pádua, e no qual este tencionava demonstrar, a partir da história, a autonomia do Sacro Império Romano-Germânico em relação à Igreja Romana. Entende-se, portanto, que o tratado possui uma conexão direta com o Defensor Pacis, e que está imerso na mesma conjuntura, dando continuidade aos propósitos políticos e ideológicos de Marsílio, quais sejam: atacar a supremacia pontifícia e negar quaisquer interferências do Papado sobre o Império e, de modo geral, do poder espiritual sobre o temporal. 


\section{Argumentos de legitimação do Sacro Império Romano-Germânico e da figura do Imperador no De Translatione Imperii de Marsílio de Pádua}

O tratado intitulado De Translatione Imperii foi escrito logo após o Defensor Pacis, obra maior de Marsílio de Pádua, provavelmente entre os anos de 1324 e 1326. Partindo disso, é possível desde já inferir que Marsílio continua no De Translatione Imperii os objetivos traçados no Defensor Pacis, ou seja, em termos gerais, desconstruir a plenitude de poder arrogada pelo pontífice romano e, especificamente, demonstrar a autonomia do Império. Como sustentam Bayona e Roche na introdução da tradução espanhola por nós utilizada:

La transferencia del Imperio refuta, desde la historia, el poder del Papa sobre el Emperador; y, de ese modo, completa la refutación de la plenitudo potestatis pontificia, que en El defensor de la paz se había hecho desde la razón y la Escritura. ${ }^{9}$

$\mathrm{O}$ autor inicia o tratado fazendo uma breve introdução, na qual explica previamente e detalha a organização e aquilo que pretende trabalhar no decorrer de cada capítulo da obra. O tratado, assim como o Defensor Pacis, organiza-se em doze capítulos, nos quais o autor traça uma espécie de "linha do tempo" que vai de como o Império Romano instituiu-se, consolidou-se e se desintegrou até como se instituíram os

\footnotetext{
${ }^{9}$ BAYONA, Bernardo; ROCHE, Pedro (Ed.). Marsílio de Pádua: sobre el poder del Imperio y del Papa. Madri: Editorial Biblioteca Nueva, 2004. p. 51. Grifo nosso.
} 
príncipes eleitores do Sacro Império Romano-Germânico. No decorrer dessa "linha" apareceriam também o Império Bizantino e o Carolíngio. Da mesma forma que expõe previamente o conteúdo do tratado, Marsílio também recapitula, no último capítulo, tudo o que sustentara no decorrer da obra.

Marsílio explicita já no primeiro capítulo que o tratado é um complemento ao que já escrevera no Defensor Pacis, além de uma crítica ao tratado homônimo escrito por Landolfo Colonna, do qual discorda. $\mathrm{O}$ autor deixa claro seu objetivo, que é analisar por meio de quem e de que maneira a sede Imperial Romana transferiu-se dos romanos aos gregos, dos gregos aos francos e, por fim, dos francos aos germanos. Para tanto, Marsílio afirma que compreende o Império Romano não como a monarquia ou o governo da cidade de Roma, mas, em outro sentido, como "[...] la monarquía universal o general del mundo entero, o al menos de la mayoría de las provincias, tal como se desarrolló la ciudad de Roma y su govierno" ${ }^{10}$ (grifo nosso).

Para alcançar seu objetivo, Marsílio de Pádua afirma ser importante recordar a origem e a evolução de Roma, retornando, para isso, ao passado mítico da cidade e sua ligação com Enéias de Tróia. Segundo o autor, Roma seria uma árvore que, apesar de inicialmente pequena, veio a crescer e tornar-se a maior de todas, sob a sombra da

10 PÁDUA, Marsílio de. La transferencia del Imperio. In: BAYONA, Bernardo; ROCHE, Pedro. Marsílio de Pádua: sobre el poder del Imperio y del Papa. Madrid: Editorial Biblioteca Nueva, 2004. p. 168. 
qual descansariam todos os reis do mundo. Este desenvolvimento e o fato de os romanos terem submetido todos os povos do mundo a sua autoridade decorrem, para Marsílio, do adestramento nas armas, da liberdade e da justiça dos romanos, bem como das alianças estabelecidas com outros povos. Logo, os romanos teriam subjugado o mundo pela sua própria virtude, de modo que a história de Roma confundir-se-ia com a história de toda a espécie humana.

Ao falar sobre o Império Romano, no segundo capítulo, Marsílio afirma que Otávio Augusto foi o primeiro Imperador, e não Júlio César, considerado por ele um violador e usurpador da República. O Império teria se mantido sem mudanças até Constantino, durante "treinta y tres emperadores y trescientos cincuenta y cuatro años y quince meses" 11 . Constantino mudou a sede do Império para o Oriente, à cidade de Bizâncio, a partir de então chamada Constantinopla, que passou a gozar de todas as prerrogativas da antiga Roma. Constantino teria ainda concedido certos privilégios ao pontífice romano de então, São Silvestre. Dessa forma, os legítimos herdeiros de Roma tornaramse, ao menos temporariamente, os bizantinos.

Marsílio afirma que o "domínio pacífico" do Império sobre o Oriente durou até Heráclio, quando os povos orientais começaram a rebelar-se contra o governo tirânico do Imperador.

${ }^{11}$ Id, Ibid. p. 170. 
El motivo por el que los Orientales, es decir, los Persas, los Árabes, los Caldeos y los demás pueblos vecinos se desvincularon del dominio del Imperio Romano, fue el reinado tiránico de Heraclio. $^{12}$

Essa rebelião dos povos orientais contra o domínio bizantino teria também se manifestado em nível religioso, tendo como personagem central a figura de Maomé, cuja proposta religiosa incorporaria influências judaicas e cristãs. Segundo Marsílio, Maomé teria propósitos políticos ao criar o islamismo, assim como os gregos, que teriam adotado um culto diferenciado para fugir da obediência à Igreja Romana. Maomé teria conseguido, através de seus ensinamentos e da imposição pela força, dominar completamente os povos orientais e levá-los a rebelar-se contra o Império; além disso, ele teria também conseguido expandir sua crença "[...] más por la violencia de la guerra que por la predicación"13.

Marsílio afirma que o Império manteve-se em mãos gregas até Constantino VI, quando foi transferido aos francos. A transferência teria se iniciado, no entanto, em virtude da querela entre o Imperador Leão III e a Igreja Romana, à época liderada por Gregório III, acerca da veneração de imagens nas igrejas. O pontífice teria, sem ter autoridade para tanto, se rebelado contra o Império e buscado desvincular-se de sua

12 PÁDUA, Marsílio de. La transferencia del Imperio. In: BAYONA, Bernardo; ROCHE, Pedro. Marsílio de Pádua: sobre el poder del Imperio y del Papa. Madrid: Editorial Biblioteca Nueva, 2004. p. 172.

${ }^{13}$ Id. Ibid. p. 176. 
dominação. Apesar de concluída posteriormente, a transferência do Império surgiria, portanto, nesse contexto, a partir do papa Estevão II, o qual teria decidido pela mudança na época em que Constantino V era imperador e Pepino rei dos francos. Ao tratar da ascensão de Pepino e da deposição de Childerico, Marsílio faz questão de rechaçar argumentos em favor de uma intervenção papal nos acontecimentos; para ele, Pepino teria sido eleito de maneira legítima, já que:

[...] la deposición de un rey y la instauración de outro, por una causa razonable, nunca es competencia de un obispo o de algún clérigo o del colegio de éstos, sino del conjunto de los habitantes de un país, de los ciudadanos y nobles o de sua mayoría prevalente $[\ldots] .{ }^{14}$

Dando continuidade ao seu pensamento, Marsílio afirma que o pontífice romano é que teria pedido a ajuda de Pepino contra Astulfo, rei dos lombardos, que havia tomado bens temporais da Igreja. Pepino teria vencido Astulfo e recuperado tais bens, entregando-os posteriormente à Igreja. A Igreja Romana colocara-se, assim, sob a proteção dos francos, aos quais recorreu novamente no reinado de Carlos Magno, filho de Pepino, contra Desidério, filho de Astulfo. Carlos Magno teria derrotado Desidério e restituído novamente os bens temporais à Igreja; além disso, teria também obtido o reconhecimento e

${ }^{14}$ Id. Ibid. p. 178. 
a submissão de todas as cidades da Península Itálica. O papa, à época Adriano I, como forma de reconhecimento aos favores de Carlos Magno, teria concedido a ele o título de "Patrício dos Romanos", dando a ele a prerrogativa de investir bispos e arcebispos, bem como de eleger o próprio pontífice romano. Marsílio salienta que, apesar de não ter utilizado o direito de eleger o pontífice, Carlos Magno nunca o renunciou.

Carlos Magno teria também ido ao Oriente, a pedido de Constantino VI, e o ajudado a recuperar a Terra Santa com o consentimento do rei dos persas, que ganhou sua benevolência por meio de preciosos presentes. De volta a Roma para a celebração do Natal, o "siempre victorioso [...] gran y pacífico"15 Carlos Magno foi coroado Imperador Augusto pelo papa Leão III e aclamado pelo povo romano. A partir de Carlos estaria transferido o Império dos gregos aos francos: "Esta transferencia del Império de los Griegos a los Francos se mantuvo entre los Francos durante siete generaciones, es decir, el reinado de siete emperadores, más de ciento trés años" ${ }^{16}$.

O Império manteve-se nas mãos dos francos até Arnulfo, já que seu filho, último descendente de Carlos Magno, foi derrotado por Berengário antes de ser coroado imperador. Berengário teria reinado de

15 PÁDUA, Marsílio de. La transferencia del Imperio. In: BAYONA, Bernardo; ROCHE, Pedro. Marsílio de Pádua: sobre el poder del Imperio y del Papa. Madrid: Editorial Biblioteca Nueva, 2004. p. 186.

${ }^{16}$ Id. Ibid. p. 187. 
modo tirânico na Península Itálica e perseguido duramente a Igreja Romana, a qual viu-se obrigada a pedir ajuda ao duque da Saxônia, Otto I, o qual derrotou Berengário e obrigou o papa João XII a renunciar, dado que "no era un verdadero pastor, sino más bien um mercenario"17. Em lugar de João XII, foi nomeado pontífice Leão VIII, o qual concedeu a Otto os mesmos benefícios que Adriano concedera a Carlos Magno, de forma que o Império foi novamente transferido, desta vez dos francos aos germanos.

O último acontecimento do qual Marsílio trata é a instituição dos príncipes eleitores do imperador. Os sete eleitores, quatro leigos e três clérigos, teriam sido instituídos em tempos de Otto III e do papa Gregório V. Tal instituição baseia-se, segundo o autor, no fato de que a virtude deveria ser o critério maior para a escolha de um Imperador, e não simplesmente seu sangue, ou seja, seria melhor eleger um novo imperador com base num colégio de eleitores que simplesmente consagrar seu descendente. Essa premissa também está vinculada ao que já vimos no Defensor Minor, já que o príncipe seria escolhido pelos representantes de todo o povo, o que está plenamente de acordo com o que Marsílio fala sobre o Supremo Legislador Humano ${ }^{18}$.

\footnotetext{
${ }^{17}$ Id. Ibid. p. 188.

18 "Igualmente, conforme a lei humana há também um legislador que é o conjunto dos cidadãos, ou sua parte mais relevante, ou ainda, o supremo Príncipe dos romanos, chamado imperador" (DM, XIII, 9). PÁDUA, Marsílio de. Defensor Menor. Petrópolis: Vozes, 1991. p. 94.
} 
Os eleitores do Império seriam: o arcebispo de Colônia, representante da Itália; o arcebispo de Tréveris, representante da França; o arcebispo de Mogúncia, representante da Alemanha; o marquês de Brandemburgo; o duque da Saxônia; o duque da Baviera; e o rei da Boêmia. No último capítulo do tratado, Marsílio afirma que a eleição é o critério de validade da escolha e não a coroação pelo papa; para ele, o imperador "[...] ha de ser coronado por el obispo Romano para dar solemnidad, pero no porque sea en modo alguno necesario"19.

\section{O lugar da história na legitimação do Sacro Império Romano- Germânico}

Pudemos perceber que o tratado De Translatione Imperii é, sem dúvidas, de caráter notavelmente histórico. Marsílio desenvolve uma narrativa na qual busca encontrar as "origens" do Sacro Império e, para isso, remonta ao Império Romano e perpassa o Império Bizantino e o Império Carolíngio:

En primer lugar, trataremos de la transferencia de la sede Imperial Romana, por medio de quién o de qué personas y de qué manera, pasó de hecho de los Romanos a los Griegos, luego de los Griegos a los

19 PÁDUA, Marsílio de. La transferencia del Imperio. In: BAYONA, Bernardo; ROCHE, Pedro. Marsílio de Pádua: sobre el poder del Imperio y del Papa. Madrid: Editorial Biblioteca Nueva, 2004. p. 190. 
Galos o Francos y, más reciente, de los Francos o Galos a los Germanos. ${ }^{20}$

Ao longo desses mais de mil anos de história, de acordo com Marsílio, o Império, que ele entende como uma "monarquia universal", transferiu-se de mãos em mãos e por fim chegou aos germanos. Como veremos, a ideia de "transferência do Império", ou Translatio Imperii, será um conceito de suma importância para a construção da legitimidade imperial, não apenas na obra marsiliana.

Para retornar aos romanos e narrar a transferência do Império, Marsílio utiliza "fontes", obras de outros autores, desde clássicos até praticamente contemporâneos seus. Alguns desses autores, citados diretamente por Marsílio, são: o já mencionado Landolfo Colonna, Martinus Polonus, Eusébio de Cesareia e Isidoro de Sevilha. Segundo Marsílio, seu tratado sobre a translação do Império é uma resenha crítica de outro, escrito pelo supracitado Landolfo Colonna:

Después de Haber escrito en el tratado El defensor de la paz sobre la institución del principado Romano y de cualquier otro gobierno, sobre una nueva transferencia o sobre cualquier otro cambio relativo al gobierno, y después de Haber dicho por quién y de qué manera puede y debe hacerse según la razón del derecho, ahora, en estas páginas, queremos

${ }^{20}$ PÁDUA, Marsílio de. La transferencia del Imperio. In: BAYONA, Bernardo; ROCHE, Pedro. Marsílio de Pádua: sobre el poder del Imperio y del Papa. Madrid: Editorial Biblioteca Nueva, 2004. p. 168. 
reseñar, críticamente, el tratado De la transferencia de la sede Imperial, atenta recopilación de crônicas hecha por el venerable sátrapa romano Landolfo Colonna, pues nuestra opinión disiente de la suya en algunos pasajes, sobre todo en los que há lesionado los derechos del Imperio según su propio parecer y sin prueba suficiente. ${ }^{21}$

Ao longo do tratado é perceptível que Marsílio utiliza tais referências como "fontes", criticando-as quando necessário e as usando como "provas" das teses às quais pretende dar sustentação teórica. No entanto, como demonstra José Antônio de C. R. de Souza ${ }^{22}$, não há uma crítica documental ou algo similar, nem mesmo exatidão nas datas; as "fontes" são utilizadas unicamente no intuito de comprovar os propósitos políticos do autor.

O propósito central da obra, como já apontado, é demonstrar que o Sacro Império Romano-Germânico é o verdadeiro "descendente" do Império Romano; tal "ascendência histórica", como veremos, conferiria ao Sacro Império legitimidade como maior autoridade secular na Cristandade Latina. Além disso, Marsílio busca esclarecer sua tese segundo a qual o Império, bem como toda autoridade secular, tem origem independente das autoridades espirituais, e nessa empreita a história ocuparia um lugar central. Para analisarmos essas questões,

\footnotetext{
${ }^{21}$ Idem.

${ }^{22}$ SOUZA, José Antônio de C. R. de. Scientia historica e philosophia politica no tratado Sobre a Translação do Império de Marsílio de Pádua. Veritas, Porto Alegre, v. 43, n. 3, set. 1998, p. 449-451. Passim.
} 
iremos inicialmente refletir sobre os usos da história na Idade Média, a importância da história como fator de legitimação para o Império e, por fim, os usos que o próprio Marsílio faz da história ao longo do tratado.

Segundo Philippe Ariés ${ }^{23}$, Santo Agostinho teria concebido a primeira "filosofia da história", a qual teria, por sua vez, influenciado o pensamento e a sensibilidade medievais. A história seria, assim, elemento fundamental da espiritualidade da Igreja Romana, inclusive para a criação de "mitos historicizados". O que o autor chama de "historicidade" teria imperado no cristianismo medieval e, consequentemente, pesaria como elemento de validade e veracidade para toda a Cristandade Latina. A história teria, assim, uma relevância muito grande para o homem medieval:

Assim, a vida medieval baseava-se no precedente histórico, na recordação do passado: nada vale o que já foi; uma falta contra o antigo uso é uma perigosa novidade. Nenhuma sociedade humana ligou tanto sua condição presente à ideia que fazia do passado $[\ldots] .^{24}$

O passado teria um sentido existencial no Medievo, dada a importância da recordação e a devoção para com o passado, expressa, por exemplo, através da iconografia. Nesse sentido, e também devido a

${ }^{23}$ ARIÉS, Philippe. O engajamento do homem moderno na história; A atitude diante da história: na Idade Média. In: O tempo da história. Rio de Janeiro: Francisco Alvez, 1989. p. 48-94.

${ }^{24}$ Id. Ibid. p. 69. 
influências romanas e judaico-cristãs, os homens medievais compuseram uma "história universal", através da qual os acontecimentos do passado seriam vistos numa ótica cristã, simultaneamente sincrônica e universal.

A história, apesar de inicialmente vinculada unicamente à ideologia eclesiástica, aos poucos se distanciou e passou também a ser utilizada para propósitos laicos, como a teorização política. Como nos mostra José Antônio de Souza:

[...] desde a segunda metade do século XIII, no Ocidente Latino os cronistas, ou historiadores de então, passaram a desempenhar um relevante papel cultural, na condição de preservadores da memória das gestas de um povo ou de uma instituição ou de um grupo social, mister esse que se tornou mais importante, ainda a partir da Idade Média Tardia, quando da emergência e consolidação das monarquias nacionais. Para não irmos buscar exemplos longínquos das nossas raízes peninsulares, baste mencionar os cronistas lusitanos Fernão Lopes (séculos XIV-XV), Rui de Pina (século XV) e o castelhano Pero López de Ayala (1332-1407), igualmente chanceler de Castela. ${ }^{25}$

${ }^{25}$ SOUZA, José Antônio de C. R. de. Scientia historica e philosophia politica no tratado Sobre a Translação do Império de Marsílio de Pádua. Veritas, Porto Alegre, v. 43, n. 3, set. 1998. p. 645. 
No sentido de uma nova reflexão leiga sobre o poder no final da Idade Média, Olivier $\mathrm{Nay}^{26}$ aponta, por exemplo, para uma concepção cada vez mais concreta e impessoal e menos religiosa do poder político. Essa "secularização das ideias políticas" afetou a representação da coletividade humana, entendida não mais apenas como societas christiana, mas também como societas humana. Tal movimento de "secularização" apresentou-se também no entendimento e nos usos feitos da história no final do Medievo, quando a história passou a ser cada vez mais uma arma de guerra no campo de batalha da teoria política. Nessa nova conjuntura, a história seria utilizada tanto como arma de ataque quanto de defesa:

[...] um outro dado relevante, encontrado nas obras de filósofos políticos que viveram na Idade Média Tardia, consistiu em recorrer aos relatos históricos (recentes ou remotos) como mais uma via ou caminho para demonstrar que os adversários estavam errados quanto à teoria, à posição e à verdade que pretendiam defender. Dante Alighieri na Monarquia, Marsílio no Defensor da Paz e Ockham em muitos de seus tratados, por exemplo, na Epístula, no An Princeps, no Brevilóquio, na Consulta e no De Imperatorum et Pontificum Potestate usaram este recurso. Aliás, o primeiro filósofo político medieval, João de Salisbúria, no Policraticus, agiu dessa maneira, como outrora já

${ }^{26}$ NAY, Olivier. História das ideias políticas. Petrópolis: Vozes, 2007. 
haviam feito Platão e Aristóteles em seus escritos políticos. $^{27}$

Como pudemos perceber, a história foi utilizada como elemento de legitimidade tanto pela Igreja Romana como por autoridades seculares, entre as quais está o Império medieval. Como demonstra o professor José Manuel Nieto Soria ${ }^{28}$, a ideia de uma translatio imperii foi parte integrante da construção do mito imperial durante a Idade Média. Segundo essa ideia, o Império seria uma entidade universal e atemporal, que se manifestaria em diferentes épocas ao longo da história, seguindo ciclos de surgimento, amadurecimento, declínio e renascimento. Em tal concepção estaria embutida ainda a esperança de melhoria ao longo do tempo, de recuperação de uma "idade de ouro" passada:

[...] El desarrollo histórico es una forma de repetición, de corrupción y de degeneración. El tiempo se constituye en agente de degeneración y corrupción, no de creación. La história queda detenida, no habiendo posibilidad de progreso. En esta visión catastrofista existe una edad de oro perdida, con respecto a la cual se ha establecido la ilusión de la recuperación, puesto que, a fin de

${ }^{27}$ SOUZA, José Antônio de C. R. de. Scientia historica e philosophia politica no tratado Sobre a Translação do Império de Marsílio de Pádua. Veritas, Porto Alegre, v. 43, n. 3, set. 1998. p. 646.

${ }^{28}$ NIETO SORIA, José Manuel. El Imperio medieval como poder público: problemas de aproximación a un mito político. Anales de la XXIII Semana de Estudios Medievales de Estella. [s.1./s.d.]. p. 403-440. 
cuentas, la translatio siempre es una recuperatio o, al menos, una esperanza de recuperatio. ${ }^{29}$

O apresentado por Nieto Soria aplica-se plenamente à obra de Marsílio de Pádua, como aponta o próprio autor:

En pleno siglo XIV, cuando escribe Marsilio de Padua, nadie pone em duda la perspectiva que del Imperio ofrece la translatio, esto no impide que, ya no en el plano del pensamiento mítico, sino del pensamiento racional, exista una diversidad interpretativa en torno a su significado exacto $y$, sobre todo, a sus efectos políticos concretos referidos a quién sea el propietario de la autoridad resultante de esa translatio. Es en esos términos, completamente ajenos - em ló discursivo al enfoque mítico, como lo plantea, por ejemplo, el propio Marsilio de Padua, quien declara como fuentes de conocimiento la razón, el derecho, las crônicas y las historias [...]. ${ }^{30}$

Marsílio parece estar alinhado à ideia de translação do Império, tanto que é a isso que dedica seu tratado, porém não mais de um ponto de vista "mítico", mas sim pretensamente racional e aplicado claramente ao propósito de dar legitimidade ao Sacro Império, visto pela lógica da translatio como herdeiro e sucessor do Império Romano e, logo, detentor da suprema autoridade secular. Nesse sentido,

\footnotetext{
${ }^{29}$ Id. Ibid. p. 416.

${ }^{30}$ NIETO SORIA, José Manuel. El Imperio medieval como poder público: problemas de aproximación a un mito político. Anales de la XXIII Semana de Estudios Medievales de Estella. [s.1./s.d.]. p. 416. Grifo nosso.
} 
Marsílio, ao longo do tratado, indica momentos de rupturas e continuidades nos quais o Império universal foi recuperado e, na sequência, novamente entrou em declínio. As causas para tais recuperações e consequentes declínios, bem como as causas para a própria translação, são, no entanto, completamente humanas, explicadas à luz da história, da razão e da vontade.

É possível ainda inferir se Marsílio acreditava numa renovatio imperii a partir de Luís da Baviera, e se a narrativa das translações anteriores não seria também uma forma de alerta ao Sacro Império Romano-Germânico para que não viesse a cometer os mesmos "erros" e para que o Império pudesse ser finalmente "restaurado" como única e suficiente autoridade secular. Nesse sentido, a história apareceria também como magistra vitae, com a qual os homens do presente poderiam aprender a imitar os acertos e evitar os equívocos do passado. Passemos agora à análise da forma como Marsílio de Pádua apresenta e utiliza a história no De Translatione Imperii.

Como demonstra Talita Cristina Garcia ${ }^{31}$, a partir da "redescoberta" de Aristóteles no século XIII houve uma crescente busca por bases racionais para a política, e Marsílio de Pádua, considerado por Etienne Gilson ${ }^{32}$ como exemplo de averroísmo político, se encaixaria perfeitamente nessa tendência. A partir dessa análise conjuntural,

\footnotetext{
${ }^{31}$ GARCIA, Talita Cristina. O uso da história na obra política de Marsílio de Pádua. Anais do XXVI Simpósio Nacional de História - ANPUH. São Paulo, jul. 2011.

${ }^{32}$ GILSON, Etienne. A filosofia na Idade Média. São Paulo: Martins Fontes, 1998.
} 
Marsílio, no De Translatione Imperii, abandonaria o providencialismo e apresentaria a história como resultante da ação dos homens, ou seja, o processo histórico aparece no tratado como algo completamente humano. Tal esforço, inserido, como vimos, em um processo maior de "secularização", teria obviamente uma finalidade política, a defesa do Império também a partir de argumentos históricos. Como aponta Souza:

[...] para o Paduano são fatores simplesmente humanos que explicam o processo histórico e, sob esta ótica, ele dessacralizou a História, antecipandose no tempo, a uma análise interpretativa dos fatos históricos que só veio a se tornar corrente com a Idade Contemporânea. ${ }^{33}$

Nessa exposição do processo histórico pelo qual o Império havia passado, Marsílio acaba também por negar qualquer participação da Igreja na construção da autoridade imperial. Em síntese, podemos afirmar que, conferindo legitimidade histórica ao Sacro Império Romano-Germânico, Marsílio lhe confere também autonomia política frente às pretensões do Papado.

${ }^{33}$ SOUZA, José Antônio de C. R. de. Scientia historica e philosophia politica no tratado Sobre a Translação do Império de Marsílio de Pádua. Veritas, Porto Alegre, v. 43, n. 3, set. 1998. p. 653. 


\section{Considerações finais:}

No presente trabalho, nosso objetivo foi o de observar os argumentos de legitimação do Sacro Império Romano-Germânico na obra de Marsílio de Pádua. Para isso, à luz do contexto do autor e das reflexões da Teoria Política Medieval, analisamos o tratado De Translatione Imperii. Nessa última seção, relembraremos as principais conclusões obtidas a partir da análise das fontes e exporemos nossas considerações finais sobre o trabalho.

No De Translatione Imperii, Marsílio continua o seu intento de desmontar a autoridade do pontífice e dar legitimidade ao Imperador, nesse caso, a partir da história. Como vimos, Marsílio constrói uma "genealogia" do Império, recorrendo à ideia de translatio imperii, e apontando o Sacro Império como legítimo herdeiro e sucessor do Império Romano. Ao buscar argumentos de autoridade na história, Marsílio utiliza uma base pretensamente racional e laica como meio para legitimar o Império. Nesse sentido, além de toda a argumentação filosófica e bíblica, o autor recorre também ao passado, demonstrando que a origem, bem como a evolução do Império ao longo do tempo se deu unicamente a partir da iniciativa humana, de forma independente da Igreja.

Ao demonstrar que o Supremo Legislador Humano é o príncipe dos Romanos, e ao identificar o Sacro Império como sucessor legítimo do Império Romano, Marsílio vincula Luís IV à imagem do 
Supremo Legislador, deixando claro que este seria a maior autoridade existente, único capaz de enunciar e aplicar a Lei Humana.

As reflexões de Marsílio de Pádua não foram produzidas desconexas da conjuntura vivida pelo autor, uma vez que, como sabemos, toda e qualquer produção humana resulta de seu contexto, influenciando e sendo influenciada por ele. Como apontamos ao longo do texto, a disputa entre Luís IV da Baviera e o papa João XXII e a situação do Sacro Império em oposição às pretensões pontifícias demandavam argumentos de legitimidade para a autoridade imperial, que se encontrava enfraquecida. A produção marsiliana respondia, portanto, a questões conjunturais, somadas, é claro, às crenças pessoais do próprio autor.

O pensamento marsiliano alinha-se, de modo bastante claro, à "secularização" das reflexões políticas do final do Medievo. Simultaneamente, o autor mantém diversas tradições, como o conceito de translatio imperii e a oposição entre virtudes e vícios, mas dá a elas uma função "moderna", no sentido de legitimar a autoridade secular em oposição à espiritual. Apesar de pouco influentes em sua própria época, as ideias de Marsílio e outras semelhantes às dele encontraram eco nas características próprias da transição da Idade Média à Modernidade, fornecendo e endossando teorias políticas de autonomia do poder temporal e civil que respondiam às necessidades únicas desse momento de transformações. 


\section{Referências}

\section{Fontes}

PÁDUA, Marsílio de. La transferencia del Imperio. In: BAYONA, Bernardo; ROCHE, Pedro. Marsílio de Pádua: sobre el poder del Imperio y del Papa. Madrid: Editorial Biblioteca Nueva, 2004. p. 165197.

\section{Bibliografia}

ARIÉS, Philippe. A atitude diante da história na Idade Média. In: $O$ tempo da história. Rio de Janeiro: Francisco Alvez, 1989. p. 62-94.

BAYONA, Bernardo; ROCHE, Pedro (Ed.). Marsílio de Pádua: sobre el poder del Imperio y del Papa. Madrid: Editorial Biblioteca Nueva, 2004.

FERNANDES, Fátima Regina. A recepção do direito romano no Ocidente europeu medieval: Portugal, um caso de afirmação régia. História: Questões e Debates, Curitiba, n. 41, p. 73-83, 2004.

. O conceito de Império no pensamento político tardo-medieval. In: DORÉ, Andréa; LIMA, Luís Filipe Silvério; SILVA, Luiz Geraldo (Org.). Facetas do Império na história: conceitos e métodos. São Paulo: Aderaldo \& Rothschild, 2008. p. 185-198.

GARCIA, Talita Cristina. A influência aristotélica na obra política de Marsílio de Pádua. Anais do XXI Encontro Estadual de História ANPUH-SP. Campinas, set. 2012.

. O uso da história na obra política de Marsílio de Pádua. Anais do XXXVI Simpósio Nacional de História - ANPUH. São Paulo, jul. 2011. 
GILSON, Etienne. A filosofia na Idade Média. São Paulo: Martins Fontes, 1998.

KNOWLES, David; OBOLENSKY, Dimitri. A Idade Média. Petrópolis: Vozes, 1974. (Nova História da Igreja, II).

LE GOFF, Jacques. A civilização do Ocidente medieval. v. 2. Lisboa: Editorial Estampa, 1984.

MIETHKE, Jürgen. Las ideas políticas en la Edad Media. Buenos Aires: Editorial Biblos, 1993.

MOSCA, Gaetano. História das doutrinas políticas desde a Antiguidade. Rio de Janeiro: Zahar, 1958.

NAY, Olivier. História das ideias políticas. Petrópolis: Vozes, 2007.

NIETO SORIA, José Manuel. El Imperio medieval como poder público: problemas de aproximación a un mito político. Anales de la XXIII Semana de Estudios Medievales de Estella. [s.l./s.d.]. p. 403-440.

RUBINSTEIN, Nicolai. Marsílio de Pádua. In: LOYN, Henry R. (Org.). Dicionário da Idade Média. Rio de Janeiro: Zahar, 1997.

SOUZA, José Antônio de Camargo Rodrigues de. As relações de poder na Idade Média Tardia: Marsílio de Pádua, Álvaro Pais O. Min., e Guilherme de Ockham O. Min. Porto Alegre: EST Edições; Porto: Faculdade de Letras da Universidade do Porto, 2010.

. Introdução. In: PÁDUA, Marsílio de. Defensor Menor. Petrópolis: Vozes, 1991.

Scientia historica e philosophia politica no tratado Sobre a Translação do Império de Marsílio de Pádua. Veritas, Porto Alegre, v. 43, n. 3, p. 643-655, set. 1998. 
SOUZA, José Antônio de Camargo Rodrigues de; BARBOSA, João Morais. $O$ reino de Deus e o reino dos homens: as relações entre os poderes espiritual e temporal na Baixa Idade Média (da Reforma Gregoriana a João de Quidort). Porto Alegre: EDIPUCRS, 1997.

SOUZA, José Antônio de Camargo Rodrigues de; BERTELLONI, Francisco; PIAIA, Gregório. Introdução. In: PÁDUA, Marsílio de. $O$ Defensor da Paz. Petrópolis: Vozes, 1997. p. 13-63.

TÔRRES, Moisés Romanazzi. O conceito de Império em Marsílio de Pádua (c. 1275-80 - c. 1342-43). Rio de Janeiro: UFRJ, 2003.

ULLMANN, Walter. Escritos sobre teoría política medieval. Buenos Aires: Peudeba, 2003.

Recebido em 26/02/2016, aceito para publicação em 19/09/2016 